\title{
PENGEMBANGAN BAHAN AJAR DIGITAL BERBASIS KEMAMPUAN PEMECAHAN MASALAH MATEMATIS PADA PEMBELAJARAN MATEMATIKA \\ (Bahan Ajar Digital Interaktif pada Materi Pertidaksamaan Nilai Mutlak Linear Satu Variabel)
}

\author{
Artisa Indariani 1), Surya Amami Pramuditya ${ }^{2)}$, Siska Firmasari3) \\ Pendidikan Matematika FKIP Univeritas Swadaya Gunung Jati, Cirebon, Jawa Barat 45132 \\ indarianiartisa@gmail.com ${ }^{1}$, amamisurya @ fkip-unswagati.ac.id ${ }^{2}$, $\underline{\text { siskafs @ fkip-unswagati.ac.id }}^{3}$
}

\begin{abstract}
ABTRACT
This research motivated by the low of students' mathematical problem-solving ability and the utilization of learning media based on technology that was not maximum. Preparation of learning materials in the form of the interactive digital module was one of the ways can overcome that problem. The method that used in this research was $\mathrm{RnD}$ with the design model ADDIE that was analysis, development of implementation design and evaluation with the restrictions of not doing the implementation stage. The instrument of collecting data in this research was the form of validation and the form of practicalities of the user senior high school students that has to get the material of linear inequality absolute value. The data that was taken though with statistics descriptive way. The validation result of the digital module gets ratings in the amount of $83,33 \%$ from media expert and $85,57 \%$ from a material expert. This interactive digital module was decent to use and very practical with the average percentage for students' high cognitive ability $88,77 \%$, medium $89,49 \%$, and low $82,97 \%$. Whereas the other user that was mathematics teacher give the percentage $84,78 \%$ so, according to them this digital module was very practical.
\end{abstract}

\section{ABSTRAK}

Penelitian ini dilatarbelakangi oleh rendahnya kemampuan pemecahan masalah matematis siswa dan pemanfaatan media pembelajaran berbasis teknologi yang belum maksimal. Salah satu cara yang dapat mengatasi masalah tersebut adalah dengan cara membuat bahan ajar berupa modul digital interaktif. Metode penelitian yang digunakan adalah $\mathrm{RnD}$ dengan model desain ADDIE yaitu analisis, desain, pengembangan, implementasi dan evaluasi dengan pembatasan tidak melakukan tahap implementasi. Instrumen pengumpulan data dalam penelitian ini adalah lembar validasi serta lembar praktikalitas pengguna siswa sekolah menengah atas yang telah mendapatkan materi pertidaksamaan nilai mutlak sebelumnya. Data yang telah diambil, diolah dengan cara statistika deksriptif. Hasil validasi modul digital mendapatkan dengan penilaian sebesar 83,33\% dari ahli media dan $85,57 \%$ dari ahli materi. Hasil praktikalitas memperoleh rata-rata presentase untuk siswa berkemampuan kognitif tinggi $88,77 \%$, sedang $89,49 \%$ dan rendah $82,97 \%$. Sedangkan guru matematika memberikan presentase sebesar 84,78\%.

Kata kunci: Bahan Ajar Interaktif, Modul, Pemecahan Masalah Matematis

\section{PENDAHULUAN}

Pada era globalisasi yang semakin maju ini semua negara berlomba-lomba dalam berbagai bidang termasuk bidang pendidikan. Keterbaharuan kurikulum dalam pendidikan dari Kurikulum Tingkat Satuan Pendidikan (KTSP) menjadi Kurikulum 2013 yang telah mengalami revisi tahun 2017 atau yang saat ini dikenal dengan Kurikulum Nasional menuntut siswa agar lebih aktif dalam kegiatan belajar mengajar [1] serta mengharuskan guru hanya menjadi fasilitator pada saat pembelajaran berlangsung.

Hal ini berakibat bahwa guru harus melakukan inovasi dalam pembelajaran yang memungkinkan siswa terlibat aktif didalamnya. Sejalan dengan hal tersebut menurut [9] pendidikan yang dilakukan harus benar-benar menciptakan lulusan-lulusan yang berkualitas, berkompetensi tinggi dan memiliki berbagai kemampuan seperti kemampuan pemecahan masalah. Hal ini bertujuan agar siswa dapat menerapkan ilmu yang 
mereka dapatkan terkait memilih dengan tepat strategi dan solusi yang akan mereka hadapi dalam kehidupan bermasyarakat.

Terkait kemampuan pemecahan masalah, tidak sedikit siswa yang memiliki tingkat kemampuan pemecahan masalah yang masih rendah terutama dalam pembelajaran matematika. Sehingga banyak siswa yang merasa kesulitan dalam menyelesaikan soal-soal matematika terutama pada materi pertidaksamaan nilai mutlak. Hal ini disebabkan oleh beberapa faktor diantaranya adalah pendidik atau guru masih menggunakan metode pembelajaran yang konvensional serta pemanfaaran media atau bahan ajar berbasis teknologi masih belum maksimal.

Banyak siswa yang mengeluhkan bahwasannya materi yang disampaikan oleh guru kurang begitu dipahami serta bahan ajar yang digunakan masih belum maksimal untuk membantu siswa dalam memahami kembali materi yang sedang dipelajari. Hal tersebut sejalan dengan observasi yang dilakukan oleh [8] bahwa salah satu yang menyebabkan siswa mengalami kesulitan dalam mengerjakan soal matematika adalah karena siswa kurang menyukai matematika dan mereka menganggap bahwa matematika merupakan pelajaran yang sullit dan kurang menyenangkan. Oleh karena itu siswa masih menggunakan cara lain untuk melengkapi pengetahuan mereka seperti penggunaan internet yang dapat berupa deskripsi penjelasan materi ataupun video pembelajaran.

Hal tersebut mengakibatkan siswa merasa kesulitan dalam melakukan pembelajaran sehingga kemampuan pemecahan masalah matematis menjadi rendah. Kemampuan pemecahan masalah matematis merupakan salah satu kemampuan matematis yang harus dimiliki oleh siswa khususnya dalam pembelajran di kelas. Menurut [5] seseorang dianggap sebagai pemecah masalah yang baik jika ia mampu menerapkan rencanarencana dan menunjukkan kemampuan metakognitif yang dimilikinya pada saat menerapkan rencana tersebut serta memeriksa kembali hasil penerapan rencana terhadap penyelesaian yang dilakukan.

Terkait dengan kemampuan pemecahan masalah matematis terdapat beberapa indikator kemampuan pemecahan masalah menurut [4], yaitu:

1. Mengidentifikasi unsur-unsur yang diketahui, dinyatakan dan kecukupan unsur yang diperlukan,

2. Merumuskan masalah matematis atau menyusun model matematis,

3. Menerapkan strategi untuk menyelesaikan masalah, dan

4. Menjelaskan atau menginterpretasikan hasil penyelesaian masalah.

Dari beberapa indikator tersebut dapat disimpulkan bahwa siswa harus menguasai kemampuan pemecahan masalah matematis serta ketercapaiannya dapat dilihat dari penguasaan seluruh indikator dalam hasil penyelesaian soal-soal matematika terkait kemampuan pemecahan masalah.

Akan tetapi berdasarkan hasil observasi yang dilakukan pada salah satu Sekolah Menengah Atas di Kabupaten Cirebon terlihat bahwa masih ada beberapa siswa yang memiliki tingkat kemampuan 
pemecahan masalah yang rendah dalam pemilihan strategi penyelesaian soal. Dalam hal ini peran guru sebagai pengajar sekaligus pendidik sangat penting. Pemilihan media ataupun sumber belajar seperti bahan ajar sangat menentukan kualitas pembelajaran. Saat ini terdapat banyak guru yang masih menggunakan bahan ajar yang bersifat konvensional seperti buku pemerintah.

Bahan ajar sendiri merupakan salah satu elemen yang penting dalam pelaksanaan pembelajaran. Menurut [2] Arlitasari, O., Pujayanto, \& R. Budiharti bahan ajar adalah bahan atau materi yang disusun oleh guru secara sistematis yang digunakan siswa di dalam pembelajaran. Jadi, bahan ajar adalah unsur penting baik itu tertulis ataupun tidak tertulis berisi materi yang disusun secara sistematis untuk mendukung pembelajaran. Terdapat berbagai macam jenis bahan ajar yaitu diantaranya, buku pelajaran, modul handout, LKS, dan bahan ajar jenis lainnya yang pada saat ini banyak digunakan di berbagai sekolah.

Buku teks merupakan salah satu sumber belajar berupa bahan ajar yang masih banyak digunakan oleh sebagian besar sekolah di Indonesia. Namun menurut [6], penggunaan bahan ajar cetak ini sukar untuk menyajikan gambar gerak untuk mengajarkan langkah atau prinsip psikomotorik. Sebagian siswa mengeluhkan pemakaian bahan ajar berupa buku cetak kurang efektif dan cenderung tidak menyajikan materi secara lengkap. Untuk itu perlunya inovasi yang dilakukan oleh guru atau pendidik terhadap bahan ajar ini.

Berdasarkan uraian tersebut maka disini perlu dikembangkan suatu bahan ajar yang bersifat digital dan interaktif yang dapat digunakan oleh siswa baik dalam pembelajaran di dalam kelas ataupun secara mandiri tanpa adanya guru atau seorang tutor. Berdasarkan penelitian yang dilakukan oleh [7] yang berjudul Pengembangan Bahan Ajar Interaktif untuk Meningkatkan Kemandirian Belajar Siswa pada Materi Pembelajaran Akuntansi yang menghasilkan bahan ajar berupa CD pembelajaran interaktif menggunakan Adobe Flash Profesional CS6 yang terbukti dapat meningkatkan kemandirian siswa dalam belajar akuntansi tanpa didampingi oleh guru atau instruktur.

Berdasarkan pemaparan di atas maka pada penelitian ini akan difokuskan pada Pengembangan Bahan Ajar Digital Interaktif Berbasis Kemampuan Pemecahan Masalah Matematis pada Materi Pertidaksamaan Nilai Mutlak Linear Satu Variabel. Untuk itu berdasarkan latar belakang tersebut, tujuan dilakukannya penelitian ini adalah untuk merancang bahan ajar digital interaktif berbasis kemampuan pemecahan masalah matematis pada pembelajaran matematika khususnya pada materi pertidaksamaan nilai mutlak linear satu variabel yang valid dan praktis.

\section{METODE PENELITIAN}

Metode penelitian yang digunakan dalam penelitian ini adalah metode penelitian pengembangan. Adapun desain penelitian yang digunakan adalah model pengembangan ADDIE yang pada setiap singkatannya merupakan tahapan sistematis dari model penelitian pengembangan 
tersebut yakni, Analyze, Design, Develop, Implement dan Evaluate [3]. Akan tetapi karena keterbatasan waktu yang peneliti miliki maka, penggunaan model pengembangan ADDIE ini dilakukan pembatasan dengan tidak melakukan tahap implementasi. Dimana bahan ajar yang berupa modul digital dibuat dan dikembangkan sesuai dengan informasi tentang kesulitan belajar dan kebutuhan siswa yang didadapatkan pada saat melakukan observasi dan wawancara pada tahap analisis awal terhadap beberapa siswa di salah satu sekolah menengah atas di Kabupaten Cirebon.

Adapun tekhnik pengumpulan data adalah dengan dilakukannya wawancara terhadap siswa dan guru siswa serta pengajuan angket validasi terhadap ahli media, materi serta angket praktikalitas terhadap seorang guru matematika dan 9 orang siswa sekolah menengah atas yang telah mendapatkan materi pertidaksamaan nilai mutlak sebelumnya. Sedangkan teknik pengolahan data yang digunakan adalah sebagai berikut.

1. Analisis deskriptif, digunakan untuk mengolah data hasil wawancara terhadap siswa dan guru mengenai kebutuhan dan kesulitan belajar siswa.

2. Menganalisis hasil validasi bahan ajar digital oleh ahli media dan ahli materi.

3. Menaganalisis hasil praktikalitas bahan ajar digital oleh pengguna yaitu siswa dan guru matematika.

\section{HASIL DAN PEMBAHASAN}

\section{A. Analisis awal}

Pada tahap ini dilakukan observasi seperti wawancara terhadap guru matematika dan beberapa orang siswa sekolah menengah atas mengenai kesulitan belajar siswa. Dari wawancara yang dilakukan didapatkan beberapa informasi bahwasannya masih terdapat pendidik atau guru yang masih belum memanfaatkan media berbasis teknologi sebagai salah satu sumber atau bahan ajar atau alat bantu yang dapat menunjang pembelajaran. Sebagian besar guru masih menggunakan metode dan sumber belajar yang masih konvensional terutama bahan ajar. Sehingga membuat siswa kesulitan dalam mencerna materi yang disampaikan.

Tidak sedikit siswa yang mengeluhkan mengenai tidak efektif dan tidak lengkapnya bahan ajar yang mereka gunakan, sehingga siswa masih menggunakan internet untuk mendapatkan informasi materi tambahan baik itu berupa penjelasan secara deskripsi maupun video pembelajaran dari website yang menyediakan hal tersebut seperti YouTube. Beberapa masalah yang dihadapi siswa tersebut berdampak pada beberapa kemampuan matematis siswa seperti kemampuan pemecahan masalah matematis siswa yang rendah. Sehingga disini siswa mengharapkan adanya bahan ajar yang dapat menunjang pembelajaran dan membantu dalam memahami materi yang sedang dipelajari.

\section{B. Hasil validasi bahan ajar digital}

Bahan Bahan ajar berupa modul digital interaktif yang dibuat dan dikembangkan pada penelitian ini di uji kevaliditasannya oleh beberapa ahli yang terdiri dari 2 dosen yang masing-masing merupakan validator ahli media dan ahli 
materi. Berikut beberapa tampilan dari bahan ajar berupa modul digital interaktif yang dikembangkan dalam penelitian ini.

Berikut merupakan tampilan awal dari modul digital yang disesuaikan dengan materi pembelajaran matematika yang dipilih yaitu pertidaksamaan nilai mutlak linear satu variabel. Serta terdapat tampilan yang menunjukkan efek flipbook yang ada dalam modul digital, hal ini memberikan kesan nyata kepada pengguna atau siswa pada saat menggunakan modul digital.
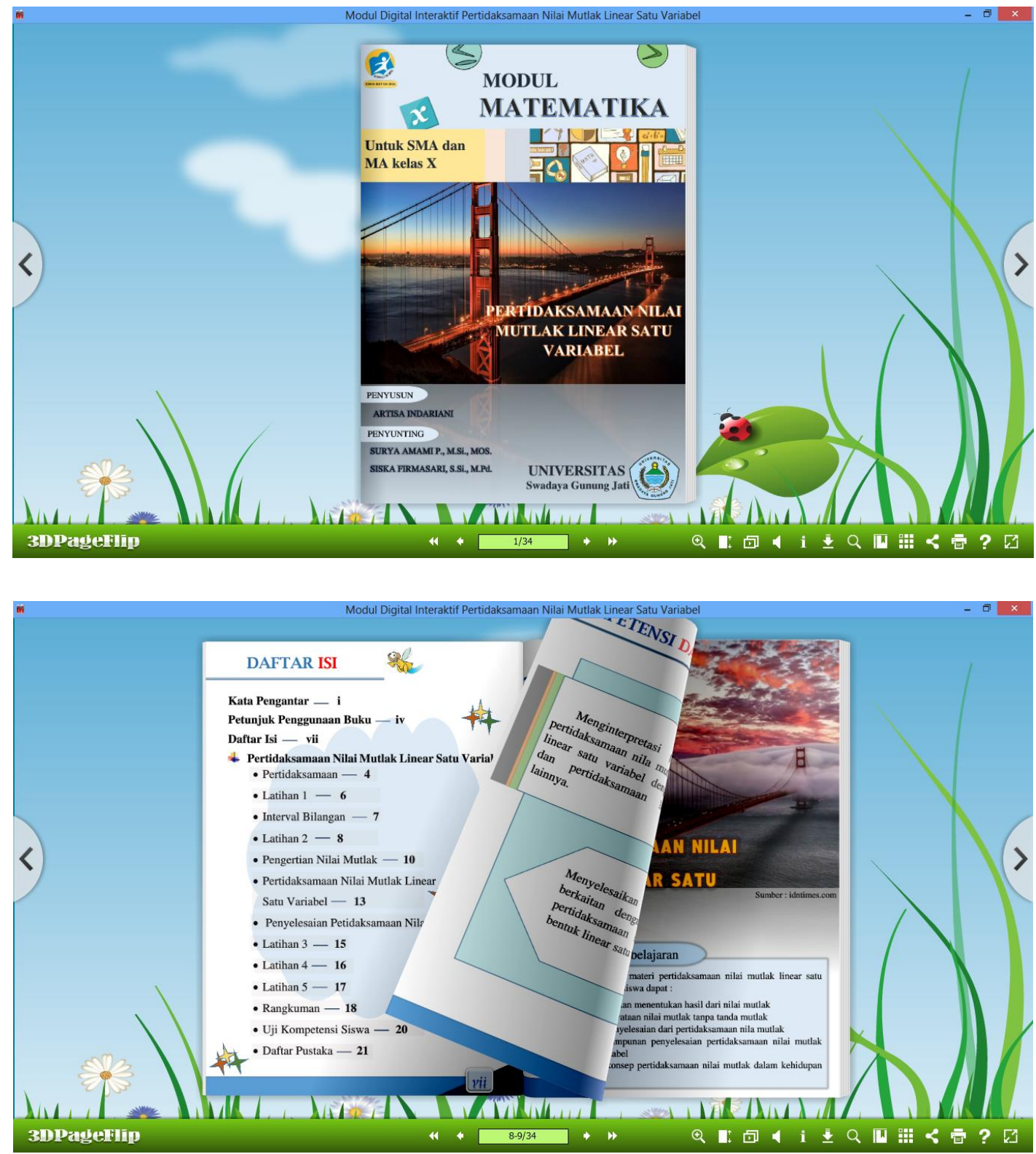

Gambar 1. Tampilan awal dan mode flipbook modul digital

Dalam modul digital ini terdapat beberapa tampilan materi dengan sajian yang unik diantaranya penampil gambar yang dapat membalikkan modul secara 90 derajat dan juga penampil gambar dalam bentuk bola dunia, untuk memperbesar gambar yang ada penampil gambar bola dunia dengan cara memilih salah satu gambar dan gambar tersebut akan menjadi besar secara otomatis untuk menyajikan materi di dalamnya. 

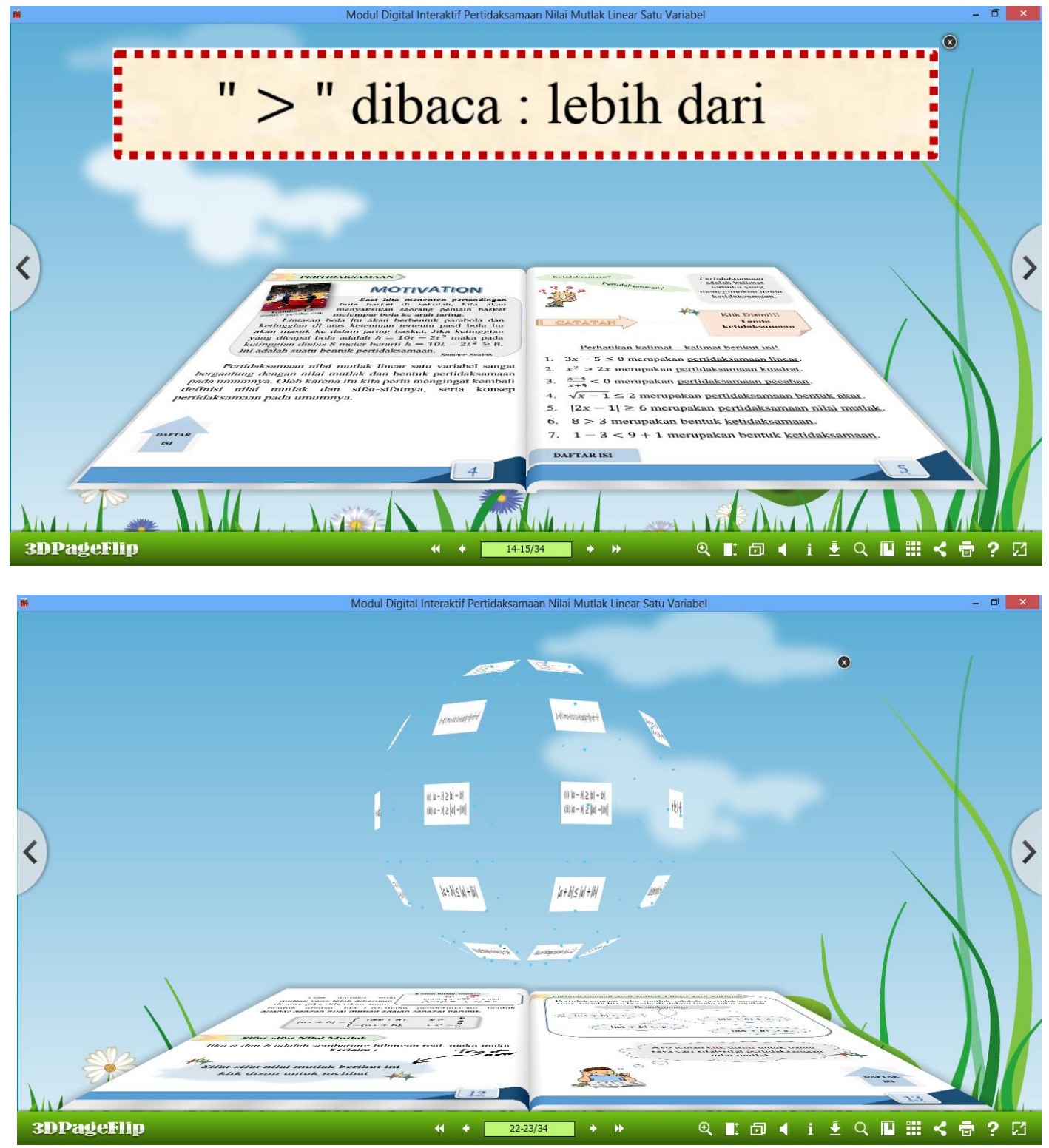

Gambar 2. Tampilan materi dengan berbagai macam penyajian gambar

Selain dapat menampilkan materi dalam bentuk variasi penyajian gambar yang unik dan menarik siswa, disamping itu dalam modul digital ini terdapat materi pengantar yang disajikan dalam bentuk video. Penyajian video ini bertujuan sebagai simulasi agar siswa tidak merasa kesulitan dalam memahami materi nilai mutlak dan juga sebagai bahan review untuk mengantarkan kepada materi selanjutnya yaitu pertidaksamaan nilai mutlak linear satu variabel.
Dalam modul digital ini terdapat beberapa soal latihan yang disajikan baik sebagai latihan evaluasi ataupun uji kompetensi siswa setelah mempelajari materi pertidaksamaan nilai mutlak linear satu variabel. Soal yang disajikan dibuat dengan feedback atas jawaban yang diberikan oleh siswa, agar siswa dapat melakukan self-assesment. 


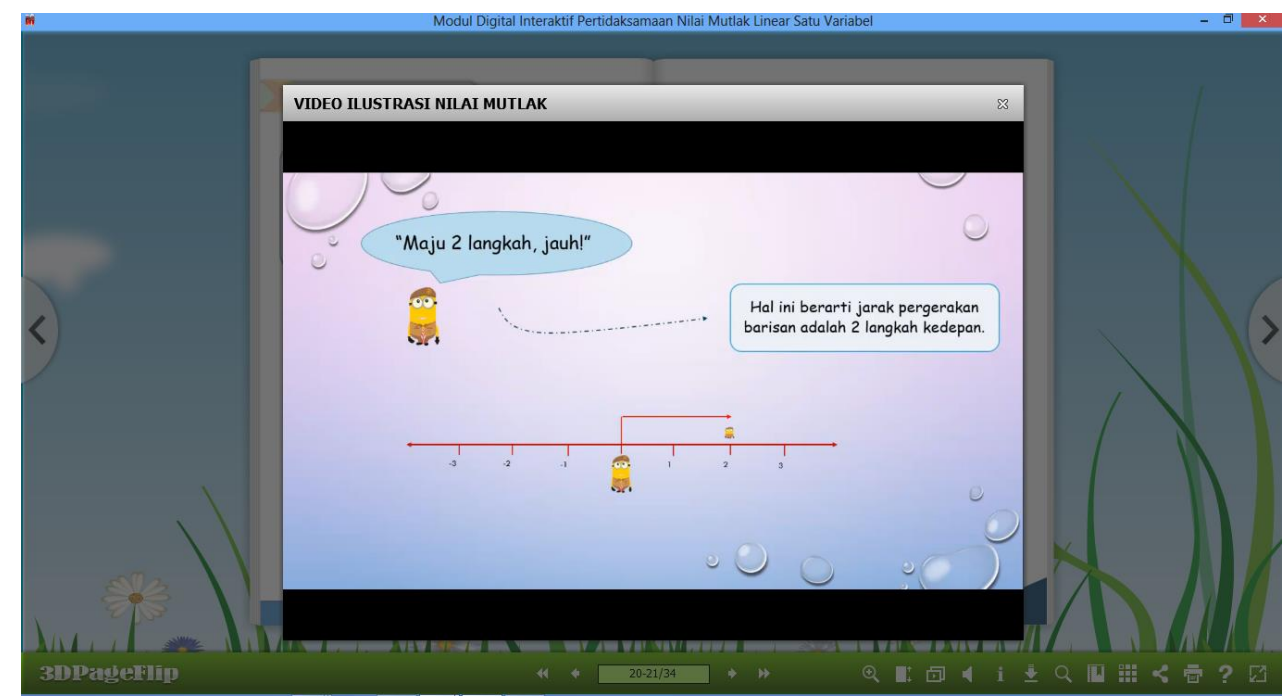

Gambar 3. Tampilan penyajian materi dengan video sebagai simulasi

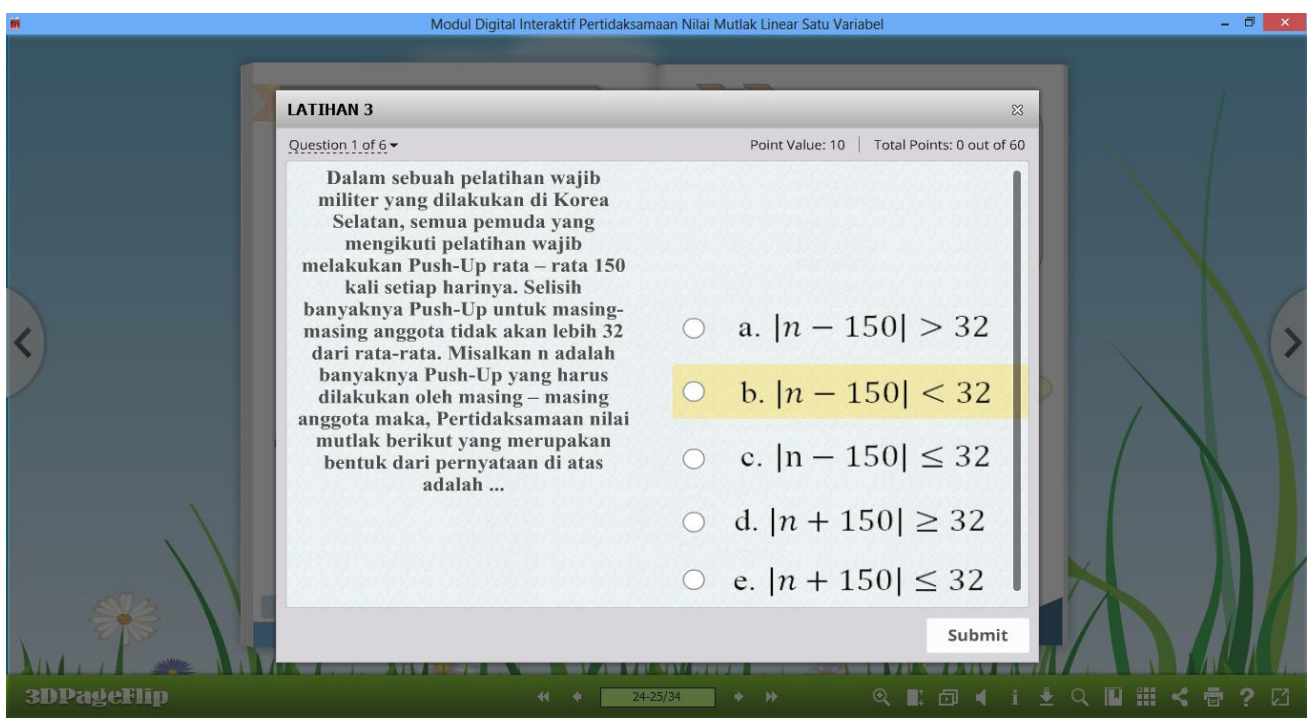

Gambar 4. Tampilan soal latihan dalam modul digital

- Setalah dilakukan uji validitas terhadap bahan ajar berupa modul digital interaktif ini, adapun hasil yang diperoleh dari uji validitas bahan ajar digital ini disajikan dalam tabel 1 berikut ini

\begin{tabular}{|c|c|c|c|}
\hline \multicolumn{4}{|c|}{$\begin{array}{c}\text { Tabel 1. Presentasi Hasil } \\
\text { Validasi Ahli Modul Digital }\end{array}$} \\
\hline $\begin{array}{l}\text { Validato } \\
\mathbf{r}\end{array}$ & $\begin{array}{c}\text { Total } \\
\text { Skor } \\
\text { yang } \\
\text { Dicapa } \\
\text { i }\end{array}$ & $\begin{array}{c}\text { Total Skor } \\
\text { yang } \\
\text { Diharapka } \\
\mathbf{n}\end{array}$ & $\begin{array}{c}\text { Kriteri } \\
\text { a } \\
\text { Validas } \\
\quad \text { i }\end{array}$ \\
\hline $\begin{array}{l}\text { Validato } \\
\text { r } 1 \text { (Ahli } \\
\text { Media) }\end{array}$ & 80 & 96 & $83,33 \%$ \\
\hline $\begin{array}{l}\text { Validato } \\
\text { r } 2 \text { (Ahli } \\
\text { Materi) }\end{array}$ & 89 & 104 & $85,57 \%$ \\
\hline
\end{tabular}

Berdasarkan hasil validasi bahan ajar digital yang dilakukan oleh validator ahli media dan ahli materi di atas, maka dapat disimpulkan secara berturut-turut menurut kriteri penskoran validasi bahan ajar untuk ahli media dan ahli materia dan cukup valid dan sangat baik.

\section{Hasil Uji Praktikalitas Bahan Ajar Digital}

Uji praktikalitas yang dilakukan dalam penelitian ini bertujuan untuk mengetahui kepraktisan serta kelayakan modul digital agar dapat digunakan dalam pembelajaran di 
kelas. Uji praktikalitas ini dilakukan terhadap salah seorang guru mata pelajaran matematika dan 9 orang siswa sekolah menengah atas yang telah mendapatkan materi pertidaksamaan nilai mutlak sebelumnya. Berikut akan disajikan hasil uji praktikalitas modul digital.

Tabel 2. Presentasi Hasil Praktikalitas Pengguna (Guru)

\begin{tabular}{ccc}
\hline Penilai & $\begin{array}{c}\text { Total Skor } \\
\text { yang dicapai }\end{array}$ & $\begin{array}{c}\text { Presentase } \\
\text { (\%) }\end{array}$ \\
\hline $\begin{array}{c}\text { Responden } \\
\text { (Guru) }\end{array}$ & 78 & $84,78 \%$ \\
\hline
\end{tabular}

Sedangkan dibawah ini akan disajikan rata-rata hasil uji praktikalitas pengguna terhadap sampel 9 orang siswa dengan masing-masing 3 orang siswa memiliki tingkat kemampuan kognitif tinggi, kognitif sedang dan kognitif rendah.

Tabel 3. Presentasi Hasil

Praktikalitas Pengguna (Guru)

\begin{tabular}{|c|c|c|c|c|}
\hline $\begin{array}{c}\text { Tingka } \\
\text { t } \\
\text { Kemam } \\
\text { puan } \\
\text { Kogniti } \\
\text { f }\end{array}$ & $\begin{array}{l}\text { Pen } \\
\text { ilai }\end{array}$ & $\begin{array}{c}\text { Tota } \\
\text { l } \\
\text { Sko } \\
\text { r } \\
\text { yan } \\
\text { g } \\
\text { dica } \\
\text { pai }\end{array}$ & $\begin{array}{c}\text { Prese } \\
\text { ntase } \\
(\%)\end{array}$ & $\begin{array}{c}\text { Rata- } \\
\text { rata } \\
\text { Tiap } \\
\text { Tingka } \\
\text { tan } \\
\text { Kemam } \\
\text { puan } \\
\text { Kogniti } \\
\text { f (\%) }\end{array}$ \\
\hline \multirow{3}{*}{ Tinggi } & S-1 & 64 & $69,57 \%$ & \multirow{3}{*}{$88,77 \%$} \\
\hline & S-2 & 91 & $98,91 \%$ & \\
\hline & S-3 & 90 & $97,83 \%$ & \\
\hline \multirow{3}{*}{ Sedang } & S-4 & 75 & $82 \%$ & \multirow{3}{*}{$88,41 \%$} \\
\hline & S-5 & 91 & $98,91 \%$ & \\
\hline & S-6 & 78 & $84,78 \%$ & \\
\hline \multirow{3}{*}{ Rendah } & S-7 & 71 & $77 \%$ & \multirow{3}{*}{$84,78 \%$} \\
\hline & S-8 & 80 & $86,96 \%$ & \\
\hline & S-9 & 83 & $90,22 \%$ & \\
\hline
\end{tabular}

Dengan demikian dari hasil uji praktikalitas di atas dapat disimpulkan bahwa bahan ajar berupa modul digital ini mempunya kriteria yang sangat praktis sehingga dapat digunakan dalam pembelajaran matematika baik itu pembelajaran yang dilakukan di dalam kelas ataupun secara mandiri.

\section{SIMPULAN DAN SARAN}

\section{A. Simpulan}

Berdasarkan hasil penelitian yang dilakukan maka didapatkan kesimpulan sebagai berikut.

1. Bahan ajar berupa modul digital interaktif berbasis kemampuan pemecahan masalah matematis pada materi pertidaksamaan nilai mutlak ini dibuat berdasarkan hasil dari analisis yang ada pada tahapan dalam model pengembangan ADD dari model ADDIE. Pada tahap analisis dilakukan analisis kebutuhan siswa dan kesulitan belajar yang siswa hadapi. Kemudian pada tahap desain dilakukan pemilihan media dan penentuan materi ajar, pembuatan rancangan media, penyusunan soal-soal tes yang akan dimasukkan ke dalam modul digital serta pembuatan produk. Penelitian ini diakhiri dengan tahap development untuk menyempurnakan produk agar dapat diujicoba pada perangkat komputer lain untuk kemudian diuji validitasannya serat kepraktiksannya. Dari hasil uji validitas dapat dilihat bahwa modul digital ini mendapatkan kriteria nilai cukup valid dengan perolehan nilai untuk validasi ahli media yaitu $83,33 \%$ dan validasi ahli materi yaitu $85,57 \%$.

2. Bahan ajar berupa modul digital interaktif ini dinilai sangat praktis. Hal ini dibuktikan dari hasil uji praktikalitas yang dilakukan terhadap 9 orang 
siswa sekolah menengah atas dengan tingkat kemampuan kognitif yang berbeda-beda. Rata-rata hasil uji praktikalitas untuk siswa dengan kemampuan kognitif tinggi adalah $88,77 \%$, kognitif sedang adalah $89,49 \% \quad$ sedangkan kognitif rendah adalah $82,97 \%$.

\section{B. Saran}

Berdasarkan kesimpulan hasil penelitian di atas, maka saran yang dapat peneliti berikan adalah sebagai berikut.

1. Karena keterbatasan waktu yang dimiliki peneliti, maka pada penelitian ini dilakukan pembatasan dengan tidak melakukan tahap Implement. Untuk penelitian selanjutnya diharapkan dapat dilakukan implementasi bahan ajar digital interaktif ini pada pembelajaran di kelas.

2. Untuk mencegah terjadinya error system pada saat menggunakan modul digital interaktif ini sebaiknya dilakukan pengecekan terhadap Windows yang digunakan pada perangkat komputer.

3. Pengembangan dari penelitian ini diharapkan modul digital interaktif berbasis kemampuan pemecahan masalah matematis pada materi pertidaksamaan nilai mutlak linear satu variabel ini dapat digunakan dalam platform Android.

\section{DAFTAR PUSTAKA}

[1] Agustina, D. Y. (2015). Pengembangan Bahan Ajar Interaktif Sebagai Pendukung Implementasi Pembelajaran
Berbasis Scientific Approach Pada Materi Jurnal Penyesuaian Siklus Akuntansi Perusahaan Jasa Di Smk Negeri 1 Jombang. Jurnal Pendidikan Akuntansi (JPAK), 3(2).

[2] Arlitasari, O., Pujayanto, P., \& Budiharti, R. (2013). Pengembangan Bahan Ajar Ipa Terpadu Bebasis Salingtemas dengan Tema Biomassa Sumber Energi Alternatif Terbarukan. Jurnal

Pendidikan Fisika, 1(1).

[3] Branch, R. M. (2009). Instructional Design: The ADDIE Approach. London: Springer science+Besiness Media.

[4] Lestari, K. E., \& Yudhanegara, M. R. (2017). Penelitian Pendidikan Matematika. Bandung: Refika Aditama.

[5] Mairing, J. P. (2016). Kemampuan Siswa Kelas VIII SMP Dalam Memecahkan Masalah Matematika Berdasarkan Tingkat Akreditasi. Jurnal

Kependidikan: Penelitian Inovasi Pembelajaran, 46(2), 179-192.

[6] Prastowo, A. (2015). Panduan Kreatif Membuat Bahan Ajar Inovatif (Menciptakan Metode Pembelajaran yang Menarik dan Menyenangkan). Yogyakarta: DIVA Press.

[7] Rahmah, A. I., Sudiyanto, \& Octoria, D. (2016). Pengembangan Bahan Ajar Interaktif Untuk Meningkatkan Kemandirian Belajar Siswa pada Pembelajaran Akuntansi. Tata Arta: Jurnal Pendidikan akuntansi, 2(1). 73-83. 
[8] Rusadi, A. P., Noto, M. S., \& Pramuditya, S. A. (2017). Desain Media Pembelajaran Berbasis Game Edukasi pada Materi Segi Empat untuk Siswa SMP Kelas VII. Repository FKIP Unswagati.
[9] Ulvah, S., \& Alfriansyah, E. A. (2016).

Kemampuan Pemecahan Masalah Matematis Siswa ditinjau melalui Model Pembelajaran SAVI dan Konvensional. Jurnal Riset Pendidikan, 2(2), 142-153. 